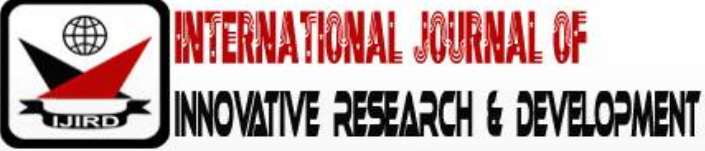

ISSN 2278 - 0211 (Online)

\section{An Appraisal of The Use of School Farm Facilities in Teaching of Animal Husbandry in Public Secondary Schools in Umuahia Educational Zone of Abia State, Nigeria}

\author{
Ikechukwu John Onyendi \\ Student, Department of Agricultural and Home Science Education, \\ Michael Okpara University of Agriculture Umudike, Nigeria
}

\begin{abstract}
:
This study aimed to determine the school farm facilities available for teaching of Animal Husbandry; the extent of use of the available school farm facilities; the constraints to the availability and use of school farm facilities and the strategies for enhancing the use of school farm facilities in the teaching of Animal Husbandry. Four research questions and hypotheses were developed. Survey research design was adopted with a sample size of 191 persons, comprising 24 Agricultural science teachers and 167 SSII students from Umuahia Educational Zone in Abia State. Data was collected through a well-structured questionnaire of 63 items, titled: Appraisal of the Use of School Farm Facilities in the Teaching of Animal Husbandry (AUSFFTAH). Data collected was analyzed using mean and standard deviation, while t-test was used to test stated hypotheses. The study revealed that 17 school farm facilities were not available and the 3 school farm facilities available were used to no extent. Respondents agreed that 13 items were constraints to the availability and use of school farm facilities.and 10 items were strategies of enhancing the availability and use of school farm facilities in teaching of Animal Husbandry. The study recommended that government and the ministry of education should ensure that trained agricultural teachers teach Animal Husbandry; policy makers and curriculum planners should ensure that practical agriculture takes place in secondary schools, external examination bodies should ensure that all external examinations on Animal Husbandry are based on skills acquired in the farm, among others.
\end{abstract}

Keywords: Animal husbandry, school farm, school farm facilities, secondary school students

\section{Introduction}

Animal Husbandry is one of the Trade/ Entrepreneurial subjects made compulsory in the senior secondary schools in the bid of enhancing skilled workforce for productivity and employment in Nigeria. By definition, it is the science of looking after and breeding animals - especially those animals used in agriculture for production purposes, research purposes or as domestic pets. It is a branch of agriculture concerned with the practice of scientific methods of animal breeding, feeding, management and disease control (Kenneth-Obosi, Chukwu, Mohammed \& Adesida, 2013). As a secondary school subject, it covers a wide range of activities such as care and grooming, livestock farming, accommodation and hygiene of livestock. In the view of the Nigerian Educational Research and Development Council NERDC, the subject should provide vocation for those who are terminating at senior secondary school education but will want to use the acquired skills and competencies for later life (Kenneth-Obosi, Chukwu, Mohammed \& Adesida, 2013). As an entrepreneurial subject, students will acquire sufficient skills when they are given the opportunity to see and practice the skills they are taught in an environment that is relevant to the job skills learnt. This draws ground from one of Prosser's theories of Vocational Education that Vocational Education will be efficient in proportion as the environment in which the learner is trained is a replica of the environment in which he must subsequently work (Olokor, 2016).In the secondary schools, so long as Animal Husbandry and agriculture generally are concerned, this environment takes the form of a school farm. Onwumere, Modebelu, \& Isiwu (2016) sees the school farm as a selected plot of land in the school environment where students carryout practical agriculture both in crop production and Animal Husbandry. In Umeanuka (2009), the school farm is defined as a miniature pilot farm where scientific findings and innovations can be tried thoroughly and adjustments made before feedback is sent to researchers for improvement. The school farm for Animal Husbandry comprises the crop production unit, pasture and livestock unit (poultry, piggery, goat and sheep house, micro-livestock section such as snailry, rabbitary, etc). These sections have to be available and effectively utilized for acquisition of skills in Animal Husbandry by students. School farm facilities include the various items found in the school farm as recommended by Nigerian Educational and Development Council NERDC (2007). The benefits of the school farm and its' facilities to the students and schools at large cannot be overemphasized. Some of these relevancies are implied in Olaitan \& Mama (2001) as the school farm serves as a source of money to the school; a store of value as it inculcates into the students the need to value what they could do or produce by themselves and for themselves; a source of transfer of knowledge; an aid in the 
development of skills in students; and a laboratory for research. Chukwudum \& Ogbuehi (2013) further added that the school farm offers farming experiences to students especially those without farming background, helps them to develop interest and love for agriculture, enhances better understanding and retention of facts; offers opportunity for demonstration of class work and; helps to develop the spirit of team work in students. However, given these benefits, it is observed that most schools do not have well equipped school farms or even school farms for teaching Animal Husbandry. This is obvious in Chukwudum \& Ogbuehi (2013) who noted that the school farm is lacking in most urban schools and even in the rural schools. Where they exist, farming operations are not taken seriously as a means of developing both practical knowledge and initial agricultural experience in pupils but rather as a means of helping teachers raise their crops and most of the lands mapped out for such farms are not suitable for farming. It noted further that keeping of farm animals in the school is far - fetched, indicating that most schools possess more of crop farms while only few had animal farms, constituting a hindrance in skill acquisition in Animal Husbandry. This also is inkling to the fact that teachers teach only the theoretical aspects of the subject in the classroom which undoubtedly is contrary to the philosophies of Vocational Education which Animal Husbandry happens to be inclusive. Consequently, Umoren (2017) added that this situation has led to students' poor entrepreneurship development resulting to their inability to establish and run small-scale agrobusiness in animal production; hence, making them roam about the street in search of non-existing white collar jobs. In schools, this situation leads to students' poor enrollment into the subject; swapping by those who are already doing the subject with other subjects like Home Economics, Technical Drawing, etc. and; laissez-faire attitude of those that have accepted the subject towards classes. It is against these consequents that this study therefore appraises the use of school farm facilities in the teaching of Animal Husbandry in senior secondary schools in Umuahia Educational Zone of Abia State. In doing so, it assesses the availability and use of school farm facilities, as well as the challenges and strategies to enhancing the use of school farm facilities in the teaching of Animal Husbandry in senior secondary schools in Umuahia Educational Zone of Abia State.

\section{Purpose of the Study}

The purpose of the study is to appraise the use of school farm facilities in the teaching of Animal Husbandry in senior secondary schools in Umuahia Educational Zone of Abia State. Specifically, the study seeks to:

- Determine the school farm facilities available for teaching of Animal Husbandry.

- Determine the extent of use of school farm facilities in the teaching of Animal Husbandry.

- Determine the constraints to the use of school farm facilities in the teaching of Animal Husbandry.

- Determine the strategies for enhancing the use of school farm facilities in the teaching of Animal Husbandry.

\section{Research Questions}

The following research questions guided the study;

- What are the school farm facilities available for teaching of Animal Husbandry?

- To what extent are the school farm facilities available used in the teaching of Animal Husbandry?

- What are the constraints to the use of school farm facilities in the teaching of Animal Husbandry?

- What are the strategies for enhancing the use of school farm facilities in the teaching of Animal Husbandry?

\section{Hypotheses of the Study}

- There is no significant difference in the mean rating of the responses of the teachers and students on the school farm facilities available for teaching of Animal Husbandry.

- There is no significant difference in the mean rating of the responses of the teachers and students on the extent to which the available school farm facilities are used in the teaching of Animal Husbandry.

- There is no significance difference in the mean rating of responses of the teachers and students on the constraint to the use of school farm facilities in the teaching of Animal Husbandry.

- There is no significance difference in the mean rating of responses of the teachers and students on the strategies of enhancing the use of school farm facilities in the teaching of Animal Husbandry.

\section{Methodology}

This study adopted a Survey research design. The study was conducted in 2019 in Umuahia Educational Zone of Abia State with the population of 861 comprising 24 Agricultural science teachers (also teaching Animal Husbandry) and 837 senior secondary II students offering Animal Husbandry as an elective in its 60 public secondary schools. The sample size for this study was 191 respondents consisting of all the 24 agricultural science teachers (also teaching Animal Husbandry) and 167 senior secondary II students in the public secondary schools. This sample size for students was $20 \%$ of a population of many hundreds as recommended by Nwana (1981:72) in Nwahunanya \& Akanwa (2008). Stratified proportionate sampling technique was used to determine the number of students selected in each local government in Umuahia educational zone using a sampling fraction of 0.19. Simple random sampling technique precisely balloting without replacement was used to select the required number of students in each local government area. A structured questionnaire titled "Appraisal of the Use of School Farm Facilities in the Teaching of Animal Husbandry (AUSFFTAH)" was used for the study. The questionnaire consisted of 2 sections: A and B. Section A consisted of the status of respondents (sex and qualification) while Section B had 4 clusters. Cluster 1 based on 2 point scale(available and not available, with corresponding scores of 2 and 1 respectively) consisted of 20 items on the facilities available in the school farm for teaching of Animal Husbandry; Cluster 2 to 4 based on 4 point scale (High Extent, Moderate Extent, Low Extent and No 
Extent for cluster 2 and; Strongly Agreed, Agreed, Disagreed and Strongly Disagreed for clusters 3 and 4; and corresponding scores of 4, 3, 2 and 1, respectively for each of the clusters) consisted of 3 items on the extent of use of the available school farm facilities in the teaching of Animal Husbandry; 8 items on the constraints to the use of school farm facilities in the teaching of Animal Husbandry and 8 items on strategies for enhancing the use of school farm facilities in the teaching of Animal Husbandry. The questionnaire items were developed from review of related literature. The questionnaire was face validated for content validity by three experts from the department of Agricultural Education, Michael Okpara University of Agriculture, Umudike, Abia State. Corrections and suggestions were effected to make the final draft that was administered to the respondents. Also, an acceptable reliability index of .88 was established using Cronbach Alpha for the instrument after a pilot study with 20 respondents in Ohafia Educational Zone. Three trained research assistants administered the questionnaire and a retrieval of 96.3 percent was made. The data collected was analyzed using descriptive statistics such as mean and standard deviation while $\mathrm{t}$-test was used for testing of the null hypotheses at 0.05 level of significance. To answer research question 1, a mean cut-off point of 1.50 was established for decision making such that any item having a mean 1.50 and above was available and any item with a mean below 1.50 was regarded as not available. Real limits of numbers were utilized in decision making for research question 2 as follows: High Extent $=3.50-4.00$, Moderate Extent $=2.50-3.49$, Low Extent $=1.50-2.49$, and No Extent $=1.00-1.49$, such that any item with a mean value of 3.50 to 4.00 was regarded as high extent, 2.50 to 3.49 was regarded as moderate extent, 1.50 to 2.49 was regarded as low extent while any item with a mean value below 1.50 was regarded as no extent. A mean cut-off point of 2.50 was established for decision making in research question 3 and 4, such that any item with mean 2.50 and above was regarded as agreed while the mean below 2.50 was regarded as disagreed. The null hypothesis for any item was upheld where the $\mathrm{p}$-value was greater than the alpha value of 0.05 but was rejected where below.

\section{Results and Interpretation}

The results of the study were presented in Table $1-4$. Results presented in Table 1 revealed that 3 items out of the 20 items had their mean values ranged from 1.53 to 1.58. This showed that the mean value of each of the items was above the cut-off point of 1.50, indicating that the 3 items were available for the teaching of Animal Husbandry. The data in Table 1 also revealed that 17 out of the 20 items had their mean values ranged from 1.17 to 1.48 . This showed that the mean value of each of the items was below the cut-off point of 1.50, indicating that the 17 items were not available for the teaching of Animal Husbandry. The Table 1 also showed that the standard deviation of the items ranged from 0.38 to 0.55 . This indicated that the respondents were not very far from the mean and one another in their responses. Table 1 further revealed that 18 out of the 20 items had their p-values ranged from 0.08 to 0.96 which were greater than the alpha-value of 0.05 level of significance, indicating that there was no significant difference in the mean ratings of the responses of the respondents on the eighteen items on the facilities available in the school farm for teaching of Animal Husbandry. Based on this result, the null hypothesis for the 17 items was upheld. The Table 1 also revealed that 2 out of twenty 20 items had their p-value as 0.04 which was below the alpha-value of 0.05 level of significance, indicating that there was a significant difference in the mean ratings of the responses of the respondents on the two items of the facilities available for use in school farm. Therefore, the null hypothesis for the two items was rejected.

Results presented in Table 2 revealed that the 3 items had their mean values ranged from 1.30 to 1.47, which were within the real limit of 1.00 to 1.49. This indicated that the respondents agreed that the items were used to a no extent in the teaching of Animal Husbandry. Table 2 also revealed that each of the items had their standard deviation ranged from 1.05 to 1.08, indicating that the respondents were not very far from the mean and one another in their responses. Table 2 further revealed that 3 items had their p-value ranged from 0.07 to 0.62 which were greater than the alpha-value of 0.05 level of significance. This indicated that there was no significant difference in the mean ratings of the responses of the respondents on the extent of use of the available school farm facilities in the teaching of Animal Husbandry. Based on this result, the null hypothesis was upheld.

Results presented in Table 3 revealed that all the 13 items had their mean values ranged from 2.62 to 3.05 . This showed that the mean value of each of the items was above the cut-off point of 2.50 , indicating that all the items were constraints to the availability and use of school farm facilities in the teaching of Animal Husbandry. The Table 3 also showed that the standard deviation of the items ranged from 0.92 to 1.14. This indicated that the respondents were not far from the mean and from one another in their responses. The Table 3 further revealed that all the 13 items had their $p$ value ranged from 0.10 to 0.94 which were greater than the alpha-value of 0.05 level of significance. This indicated that there was a no significant difference in the mean ratings of the responses of the two groups of respondents on the constraint to the availability and use of school farm facilities in the teaching of Animal Husbandry. Based on this result, the null hypothesis was upheld.

Results in Table 4 revealed that all the 10 items had their mean values ranged from 2.93 to 3.71 . This showed that the mean value of each of the items was above the cut-off point of 2.50, indicating that all the items were strategies for enhancing the availability and use of school farm facilities in the teaching of Animal Husbandry. The Table 4 also showed that the standard deviation of the items ranged from 0.24 to 0.95 , indicating that the respondents were not far from the mean and from one another in their responses. Table 4 further revealed that all the 14 items had their $p$-value ranged from 0.10 to 0.94 which were greater than the alpha-value of 0.05 level of significance. This indicated that there was a no significant difference in the mean ratings of the responses of the two groups of respondents on the strategies of enhancing the availability and use of school farm facilities in the teaching of Animal Husbandry. Based on this result, the null hypothesis was upheld. 


\section{Discussion of the Finding}

The findings revealed that 17 school farm facilities such as dehorning equipment,feeding troughs, watering troughs, drugs for disease control, buddizor pliers/ castrators, debeaking equipment, egg candler, dehorning equipment, artificial inseminator, refrigerator for storing produce, animal feed, goat pen, sheep pen, rabbit hutches, pig pen, snairy and bee hives, were unavailable in the schools whereas only lanterns/ stoves, notebook for accounts and records, and poultry house were available. It also revealed that the responses of the respondents on majority of the items were not influenced by their professional status as there was no significant difference in the mean ratings of the responses of the two groups on the 18 school farm facilities available for use in the teaching of Animal Husbandry. This finding is contrary to the expectations and falls below the required facilities stated by NERDC (2007) for teaching of Animal Husbandry in schools. It also confirmed Obiyai (2017) who observed that most of the facilities for teaching of Animal Husbandry were lacking in schools.

As availability prompts use, uninfluenced, the result also revealed that the 3 facilities (lanterns/ stoves, notebook for accounts and records, and poultry house) available were used to no extent in the teaching of Animal Husbandry in secondary schools. The finding was also a confirmation of the findings of Umeanuka (2009), that teachers taught only the theoretical aspect of the subject in the classroom. Thus the success recorded by the Zone in both external and internal examinations in the subject was without practical orientation in the farm. This further unfolds that the method of teaching of Animal Husbandry in the Zone goes contrary to some of the theories of Vocational Education as propounded by Prosser that Vocational Education will be effective in proportion as it trains the individual directly and specifically in the thinking habits and the manipulative habits required in the occupation itself and; Vocational Education will be efficient in proportion as the environment in which the learner is trained is a replica of the environment in which he must subsequently work (Olokor, 2016).

The finding further revealed that the constraints to the availability and use of school farm facilities in the teaching of Animal Husbandry were lack of space for school farm and its facilities; poor supervision and inspection of school and classroom activities; high cost of equipment; etc. It also revealed that the responses of the respondents were not influenced by their professional status as there was no significant difference in the mean ratings of the responses of the two groups on the constraint to the availability and use of school farm facilities in the teaching of Animal Husbandry. This finding confirmed the findings in Obiyai (2017), that the constraints to the availability of school farm facilities were inadequate funding, high cost of equipment, embezzlement of funds meant for the purchase of construction of school farm facilities, lack of space, poor inspection of school activities, poor supervision, insecurity of the school environs and lack of interest of policy makers in support of school farm. As well as teachers' lack of zeal, teachers' incompetence and poor funding of school farm facilities as constraints to the use of school farm facilities. This finding was also in line with the constraints to the utilization of school farm as stipulated in Olaitan \& Mama (2001) which included; non-relevance of school farm in students' assessment, students' lack of interest in school farm, and shortage of professional teachers of agriculture.

The findings also revealed that uninfluenced, the strategies for enhancing the availability and use of school farm facilities in the teaching of Animal Husbandry were that only trained agricultural teachers should teach Animal Husbandry in the secondary schools, improvement on government policy to favour practical agriculture in secondary schools, all external examinations and possibly internal examinations on Animal Husbandry should examine skills acquired in the farm, etc. This finding is in line with Famiwole(2013), that the measures to improve the use and operation of school farm for skill development included: only trained agricultural teachers should teach agricultural science in the secondary schools; improvement on government policy to favour practical agriculture in secondary schools; SSCE final examination should examine skills acquired in the farm; more funds and funding should be provided/ made available to finance school farm work; involvement of agencies like ADP, Board for vocational and technical education and, ministry of education to evaluate school farm work and Present examination system should change from theory oriented to practical field project.

\section{Conclusion and Recommendation}

School farm facilities are essential for the teaching of Animal Husbandry in Senior Secondary Schools as the sole aim of the subject is to sustain students' interest in animal production and to equip them for work after school with skills involved in animal production. However, the situation is different in Umuahia Educational Zone of Abia State, where schools are poorly equipped with school farm facilities and were available, are not utilized. Hence, students are limited to theoretical aspect of the subject. Many factors contribute to the unavailability and no utilization of such facilities as xrayed in the study. The study further revealed strategies for enhancing the availability and use of school farm facilities needed for the teaching and learning of Animal Husbandry. Based on the findings and discussion made, the following recommendations were made:

- The government as well as the ministry of education should ensure that trained agricultural teachers teach Animal Husbandry in the secondary schools

- The government should ensure that more funds are made available to finance school farm and its facilities.

- The government and PTA philanthropists should assist the school by supplying school farm facilities to schools.

- Policy makers and curriculum planners should ensure that practical agriculture takes place in secondary schools.

- Agencies such as ADP, Board for Vocational and Technical Education as well as the ministry of education should involve in the supervision and inspection of school activities.

- External examination bodies such as WAEC and NECO should ensure that all external examinations on Animal Husbandry are based on skills acquired in the farm.

- The school management should adjust the school time table to include special farm operations. 
- The school management as well as teachers should ensure that the assessment of students include practical on livestock pen management as a percentage of the Animal Husbandry examination

- The school management as well as teachers should ensure that present examination system should change from theory oriented to practical field project

\section{References}

i. Chukwudum, E.O. \& Ogbuehi, U.G., (2013).Effective Utilization of the School Farm as Instructional Initiative for Developing Agricultural Interest among Primary School Children in Nigeria. Academic Journal of Interdisciplinary Studies. 2[6]. Retrieved from https:/ / www.google.com/ url?sa=t\&source=web\&cd=1 \&ved=2ahUKEwiQyb7dgq7kAhXl0eAKHWxMD5kQFjAAeg QIABAC\&url=https\%3A\%2F\%2Fwww.mcser.org\%2Fjournal\%2Findex.php\%2Fajis\%2Farticle\%2Fdownload\%2F 623\%2F645\&usg=AOvVaw3v6VLK TPE9cH-WIHZePza. Accessed on 12/ 10/2018

ii. Famiwole, R. O, (2013). Measures to Improve the Declining Usage and Operation of School Farm in Secondary Schools in Ekiti State, Nigeria. International Journal of Computational Research IJCER, 3 (7). Retrieved from http:/ / www.ijceronline.com/ papers/ Vol3_issue7/ Part-4/ D037402027.pdf. Accessed on 21/ 10/ 2018

iii. Kenneth-Obosi, O., Chukwu E.O., Mohammed W.A., \& Adesida F.A., (2013). Cosmopolitan Trade/ Entrepreneurship Series, Animal Husbandry for Senior Secondary Schools 1. Ibadan, Cosmopolitan Book Services.

iv. Nigerian Educational and Development Council NERDC (2007), Senior Secondary School Trade Curriculum. Animal Husbandry SSS1-3.Abuja, NERDC Press.

v. Nwahunanya, C.I. \& Akanwa, U.N. (2008). A Practical Guide to Research and Project Writing. Owerri, Springfield Publishers.

vi. Olaitan, S.O. \& Mama, R.O. (2001). Principles and Practice of School Farm Management, Owerri, Cape Publishers Int'l Ltd.

vii. Obiyai, K.K., (2017). Availability of Equipment and Structures in Secondary Schools as a Constraint for the Implementation of Entrepreneurship Education in Animal Husbandry Occupation in Bayelsa State, Nigeria. Higher Education Research, 2 (1), 1-5.

viii. Olokor, N., (2016). Theories of Vocational Education. In Uko, C.O., Ugboaja, C.I., Ibe, V.S.O \& Obunadike, J.C. (Eds), Foundations of Technical/Vocational Education and Training (TVET) Hi - Tech,(pp. 44-58). Uyo, IGM Ventures.

ix. Onwumere, M., Modebelu, M.N., \& Isiwu, E.C. (2016) Influence of School Farm on Teaching of Agricultural Science in Senior Secondary Schools in Ikwuano Local Government Area, Abia State. Open Access Library Journal, 3:e2742. http:/ / dx.doi.org/ 10.4236/ oalib./ / 02742. Accessed on 12/ 10/ 2018

x. Umeanuka, C.C., (2009).Skills Required by Agricultural Science Teachers for Effective Management of School Farms in Secondary Schools in Anambara State. University of Nigeria Virtual Library. Retrieved fromwww.unn.edu.ng/ internals/ repository/ view/ NzQ0Nw-. Accessed on 22/ 10/ 2018

xi. Umoren, J., (2017).Availability and Utilization of School Farms for Effective Teaching and Learning of Agricultural Science in Ikot Ekpene, Akwa Ibom State. B.Sc Project, Department of Agricultural and Home Science Education, Micheal Okpara University of Agriculture, Umudike.

\begin{tabular}{|c|c|c|c|c|c|}
\hline $\mathbf{S} / \mathbf{N}$ & Items & $\overline{\mathbf{x}}$ & $\mathbf{S}$ & $\mathbf{p}$-value & Remarks \\
\hline 1 & Dehorning equipment & 1.18 & 0.38 & 0.80 & NA; NS \\
\hline 2 & Feeding troughs & 1.48 & 0.50 & 0.04 & NA; S \\
\hline 3 & Watering troughs & 1.47 & 0.50 & 0.04 & NA; S \\
\hline 4 & Lanterns/ stoves & 1.54 & 0.50 & 0.08 & A; NS \\
\hline 5 & Notebook for accounts and records & 1.58 & 0.49 & 0.14 & A; NS \\
\hline 6 & Drugs for disease control & 1.44 & 0.50 & 0.96 & NA; NS \\
\hline 7 & Buddizor pliers/ castrators & 1.28 & 0.45 & 0.40 & NA; NS \\
\hline 8 & Debeaking equipment & 1.25 & 0.43 & 0.52 & NA; NS \\
\hline 9 & Egg candler & 1.22 & 0.42 & 0.68 & NA; NS \\
\hline 10 & Dehorning equipment & 1.17 & 0.38 & 0.86 & NA; NS \\
\hline 11 & Artificial inseminator & 1.28 & 0.43 & 0.12 & NA; NS \\
\hline 12 & Refrigerator for storing produce & 1.34 & 0.47 & 0.18 & NA; NS \\
\hline 13 & Animal feed & 1.25 & 0.43 & 0.26 & NA; NS \\
\hline 14 & Poultry house/ battery cages & 1.53 & 0.55 & 0.08 & A; NS \\
\hline 15 & Goat pen & 1.39 & 0.49 & 0.33 & NA; NS \\
\hline 16 & Sheep pen & 1.31 & 0.46 & 0.47 & NA; NS \\
\hline 17 & Rabbit hutches & 1.24 & 0.43 & 0.79 & NA; NS \\
\hline 18 & Pig pen & 1.43 & 0.50 & 0.12 & NA; NS \\
\hline 19 & Snairy & 1.24 & 0.43 & 0.56 & NA; NS \\
\hline 20 & Bee hives & 0.46 & 0.47 & NA; NS \\
\hline
\end{tabular}

Table 1: Mean Rating, Standard Deviation and T-Test Analyses of Responses of the Teachers and

Students on the School Farm Facilities Available for Teaching of Animal Husbandry (N=184)

$\bar{X}=$ Sample Mean, SD=Standard Devia tion, A=Available, NA=Not Available, S=Significant, NS = Not Significant 


\begin{tabular}{|c|c|c|c|c|c|}
\hline S/ N & Items & $\overline{\mathbf{x}}$ & $\mathbf{S}$ & $\mathbf{p}$-value & Remarks \\
\hline 1 & Lanterns/ stoves & 1.36 & 1.08 & 0.17 & NE; NS \\
\hline 2 & Notebook for accounts and records & 1.47 & 1.05 & 0.62 & NE; NS \\
\hline 3 & Poultry house/ battery cages & 1.30 & 1.06 & 0.07 & NE; NS \\
\hline
\end{tabular}

Table 2: Mean Rating, Standard Deviation and T-Test Analyses of Responses of the

Teachers and Students on the Extent of Use of the Available School Farm Facilities in Teaching of Animal Husbandry ( $\mathrm{N}=184)$

$\bar{X}=$ Sample Mean, $\mathrm{SD}=$ Standard Deviation, NE=No Extent, NS = Not Significant

\begin{tabular}{|c|c|c|c|c|c|}
\hline $\mathbf{S} / \mathbf{N}$ & Items & $\overline{\mathbf{x}}$ & $\mathbf{S}$ & p-value & Remarks \\
\hline 1 & Lack of space for school farm and its facilities. & 3.05 & 1.06 & 0.23 & A; NS \\
\hline 2 & $\begin{array}{c}\text { Poor supervision and inspection of school and classroom } \\
\text { activities. }\end{array}$ & 2.92 & 0.93 & 0.56 & A; NS \\
\hline 3 & High cost of equipment & 2.87 & 1.03 & 0.15 & $\mathrm{~A} ; \mathrm{NS}$ \\
\hline 4 & $\begin{array}{l}\text { Embezzlement of funds meant for the purchase of construction } \\
\text { of school farm facilities. }\end{array}$ & 2.65 & 1.06 & 0.78 & A; NS \\
\hline 5 & Insecurity of the school environs/ community. & 2.89 & 1.04 & 0.92 & $\mathrm{~A} ; \mathrm{NS}$ \\
\hline 6 & Lack of interest of policy makers in support of school farm. & 2.78 & 0.92 & 0.82 & A; NS \\
\hline 7 & Non relevance of the school farm to assessment. & 2.68 & 0.97 & 0.48 & $\mathrm{~A} ; \mathrm{NS}$ \\
\hline 8 & $\begin{array}{l}\text { Time constraint for practice of Animal Husbandry in the school } \\
\text { farm. }\end{array}$ & 3.03 & 0.99 & 0.94 & A; NS \\
\hline 9 & Teachers' lack of interest in the school farm. & 2.76 & 1.14 & 0.15 & A; NS \\
\hline 10 & Students' lack of interest in working at the school farm. & 2.64 & 1.06 & 0.52 & A; NS \\
\hline 11 & Scarcity of professional teachers of Animal Husbandry. & 2.90 & 1.05 & 0.40 & A; NS \\
\hline 12 & Poor funding for school farm and its facilities. & 2.76 & 1.09 & 0.10 & A; NS \\
\hline 13 & Teachers' incompetence in the teaching of the subject matter. & 2.62 & 1.12 & 0.82 & A; NS \\
\hline
\end{tabular}

Table 3: Mean Rating, Standard Deviation and T-Test Analyses of Responses of the Teachers and Students on the

Constraints to the Availability and Use of School Farm Facilities in Teaching of Animal Husbandry $(\mathrm{N}=184)$

$\bar{X}=$ Sample Mean, $\mathrm{SD}=$ Standard Deviation, $\mathrm{A}=\mathrm{Agreed}, \mathrm{NS}=$ Not Significant

\begin{tabular}{|c|c|c|c|c|c|}
\hline S/ N & $\overline{\mathbf{x}}$ & $\mathbf{S}$ & $\mathbf{p}$-value & Remarks \\
\hline 1 & $\begin{array}{c}\text { Inly trained agricultural teachers should teach Animal } \\
\text { Husbandry in the secondary schools }\end{array}$ & 3.38 & 0.59 & 0.48 & $\mathrm{~A} ; \mathrm{NS}$ \\
\hline 2 & $\begin{array}{c}\text { Improvement on government policy to favour practical } \\
\text { agriculture in secondary schools. }\end{array}$ & 3.14 & 0.36 & 0.95 & $\mathrm{~A} ; \mathrm{NS}$ \\
\hline 3 & $\begin{array}{c}\text { All external examinations and possibly internal examinations } \\
\text { on Animal Husbandry should examine skills acquired in the } \\
\text { farm. }\end{array}$ & 3.24 & 0.44 & 0.44 & $\mathrm{~A} ; \mathrm{NS}$ \\
\hline 4 & $\begin{array}{c}\text { More funds and funding should be provided/made available } \\
\text { to finance school farm and its facilities. }\end{array}$ & 3.38 & 0.59 & 0.53 & $\mathrm{~A} ; \mathrm{NS}$ \\
\hline 5 & $\begin{array}{c}\text { Involvement of agencies like ADP, Board for vocational and } \\
\text { technical education and, ministry of education in the } \\
\text { supervision and inspection school activities. }\end{array}$ & 2.93 & 0.81 & 0.83 & $\mathrm{~A} ; \mathrm{NS}$ \\
\hline 6 & $\begin{array}{c}\text { Flexibility of time for use of school facilities and personnel on } \\
\text { the part of school administration. }\end{array}$ & 3.26 & 0.46 & 0.78 & $\mathrm{~A} ; \mathrm{NS}$ \\
\hline 7 & Adjustment of school time table for special farm operations. & 3.33 & 0.58 & 0.41 & $\mathrm{~A} ; \mathrm{NS}$ \\
\hline 8 & $\begin{array}{c}\text { Government/ PTA philanthropists should supply school farm } \\
\text { facilities to schools }\end{array}$ & 3.52 & 0.51 & 0.24 & $\mathrm{~A} ; \mathrm{NS}$ \\
\hline 9 & $\begin{array}{c}\text { Practical on students livestock pen management should form } \\
\text { a percentage of the Animal Husbandry examination } \\
\text { assessment }\end{array}$ & 3.29 & 0.64 & 0.42 & $\mathrm{~A} ; \mathrm{NS}$ \\
\hline 10 & $\begin{array}{c}\text { Present examination system should change from theory } \\
\text { oriented to practical field project }\end{array}$ & 3.71 & 0.56 & 0.85 & $\mathrm{~A} ; \mathrm{NS}$ \\
\hline
\end{tabular}

Table 4: Mean Rating, Standard Deviation and T-Test Analyses of Responses of the Teachers and

Students on the Strategies for Enhancing the Availability and Use of School Farm Facilities in

Teaching of Animal Husbandry ( $\mathrm{N}=184)$

$\bar{X}=$ Sample Mean, $\mathrm{SD}=$ Standard Deviation, $\mathrm{A}=$ Agreed, NS = Not Significant 